\title{
molecules
}

ISSN 1420-3049

www.mdpi.com/journal/molecules

Review

\section{Amazonian Plant Natural Products: Perspectives for Discovery of New Antimalarial Drug Leads}

Adrian Martin Pohlit ${ }^{1, *}$, Renata Braga Souza Lima ${ }^{1}$, Gina Frausin ${ }^{1}$,

Luiz Francisco Rocha e Silva ${ }^{1}$, Stefanie Costa Pinto Lopes ${ }^{2}$, Carolina Borsoi Moraes ${ }^{3}$, Pedro Cravo ${ }^{4,5}$, Marcus Vinícius Guimarães Lacerda ${ }^{6,7}$, André Machado Siqueira ${ }^{6,7}$,

Lucio H. Freitas-Junior ${ }^{3}$ and Fabio Trindade Maranhão Costa ${ }^{2, *}$

1 Instituto Nacional de Pesquisa da Amazônia (INPA), Av. André Araújo, 2936, 69067-375 Manaus, AM, Brazil; E-Mails: renatabs1@hotmail.com (R.B.S.L.); ginafrausin@gmail.com (G.F.); luizrocha_silva@hotmail.com (L.F.R.S.)

2 Departamento de Genética, Evolução e Bioagentes, Universidade Estadual de Campinas-UNICAMP, P.O. Box 6109, 13083-862 Campinas, SP, Brazil; E-Mail: stefaniecplopes@gmail.com

3 Laboratório Nacional de Biociências (LNBio) - Centro Nacional de Pesquisa em Energia e Materiais (CNEPM) - P.O. Box 6192, 13083-970 Campinas, SP, Brazil; E-Mails: carolina.borsoi@lnbio.cnpem.br (C.B.M.); lucio.freitasjunior@lnbio.cnpem.br (L.H.F.-J.)

4 Programa de Mestrado em Sociedade, Tecnologia e Meio Ambiente. UniEVANGÉLICA-Centro Universitário de Anápolis, 75083-515 Anapólis, GO, Brazil; E-Mail: pedrovcravo@gmail.com

5 Centro de Malária e Doenças Tropicais, LA/IHMT-Universidade Nova de Lisboa, 1349-008 Lisboa, Portugal

6 Fundação de Medicina Tropical Dr. Heitor Vieira Dourado, 69040-000 Manaus, AM, Brazil; E-Mails: marcuslacerda.br@gmail.com (M.V.G.L.); amsiqueira@gmail.com (A.M.S.)

7 Programa de Pós-Graduação em Medicina Tropical, Universidade do Estado do Amazonas, 69040-000 Manaus, AM, Brazil

* Authors to whom correspondence should be addressed; E-Mails: ampohlit@inpa.gov.br (A.M.P.); fabiotmc72@gmail.com (F.T.M.C.); Tel.: +55-92-3643-3078 (A.M.P.); +55-19-3521-6594 (F.T.M.C.).

Received: 2 July 2013; in revised form: 14 July 2013 / Accepted: 18 July 2013 / Published: 2 August 2013

Abstract: Plasmodium falciparum and P. vivax malaria parasites are now resistant, or showing signs of resistance, to most drugs used in therapy. Novel chemical entities that exhibit new mechanisms of antiplasmodial action are needed. New antimalarials that block transmission of Plasmodium spp. from humans to Anopheles mosquito vectors are key to 
malaria eradication efforts. Although $P$. vivax causes a considerable number of malaria cases, its importance has for long been neglected. Vivax malaria can cause severe manifestations and death; hence there is a need for $P$. vivax-directed research. Plants used in traditional medicine, namely Artemisia annua and Cinchona spp. are the sources of the antimalarial natural products artemisinin and quinine, respectively. Based on these compounds, semi-synthetic artemisinin-derivatives and synthetic quinoline antimalarials have been developed and are the most important drugs in the current therapeutic arsenal for combating malaria. In the Amazon region, where $P$. vivax predominates, there is a local tradition of using plant-derived preparations to treat malaria. Here, we review the current $P$. falciparum and $P$. vivax drug-sensitivity assays, focusing on challenges and perspectives of drug discovery for $P$. vivax, including tests against hypnozoites. We also present the latest findings of our group and others on the antiplasmodial and antimalarial chemical components from Amazonian plants that may be potential drug leads against malaria.

Keywords: herbal remedy; Plasmodium spp.; antimalarials; drug discovery; Amazonian plants

\section{Introduction}

In the absence of clinically effective vaccines, prevention and treatment of malaria critically depend on prophylaxis and drug-based therapy [1]. However, the number of available antimalarial drugs that feature distinct mechanisms of action is low. Also, the rate at which antimalarial drug-resistance is emerging and spreading is outperforming the development of new drug entities. This is especially worrying given reports of artemisinin-resistant $P$. falciparum in Southeast Asia [2,3].

In the Amazon region, plants are widely used in traditional medicine for the treatment of malaria. In 1997, Milliken surveyed the literature on plants used for the treatment of malaria infections, fevers and related conditions (headaches, etc.) by the people of the Amazon and Caribbean regions [4]. He described antimalarial plants that are widely distributed and used throughout the Amazon region such as Quassia amara L. and Picrolemma sprucei Hook. f. (Simaroubaceae), Aspidosperma spp. Geissospermum spp. (Apocynaceae) and Ampelozizyphus amazonicus Ducke (Rhamnaceae). Recently, further works have been published on the antimalarial plants and remedies used by native Amazonian groups and local populations [5,6]. Indeed, broad scope surveys of antimalarial plant components include many Amazonian plant natural products with proven antiplasmodial activity [7,8]. Many traditionally used Amazonian plants have not yet been screened for antimalarial activity and little or nothing is known about their chemical composition thus making them interesting starting points for research on new antimalarials.

In this review we highlight the potential of Amazonian plants as sources of prospective drug leads against malaria, focusing on the findings of our drug discovery group based in Manaus (Amazonas State, Brazil) and including important findings of other groups. Specifically, isolated compounds of known molecular structure from Amazonian plants for which in vitro or in vivo antiplasmodial activity has been confirmed, are covered. Despite this, several elegant studies on plant extracts, fractions and 
compound-enriched fractions have been published by leading research groups in the past decade [9]. Also, we discuss the currently available antimalarial drug-sensitivity assays based on $P$. falciparum for screening and drug discovery. We propose that challenges may be addressed and perspectives created in P. vivax drug discovery through multidisciplinary research by laboratories located outside and within the Brazilian Amazon. Specifically, in the Brazilian Amazon there is a diversity of medicinal plants that is traditionally used to treat $P$. vivax and $P$. falciparum infections. Additionally, malaria-infected patients have access to hospitals with adequate facilities and personnel where molecular, genetic and screening studies may be performed.

\section{Malaria Drug Resistance: Urging the Discovery and Development of New Drugs}

Resistance to antimalarial drugs has been described for three of the five species of human malaria parasites, $P$ falciparum, $P$. vivax and $P$. malariae [10]. Resistance of $P$. falciparum to chloroquine (CQ), the most promising antimalarial of the 20th century, was first reported less than twenty years following its widespread use, with the first reports of resistance originating from South America and Southeast Asia at the end of the 1950's [11,12]. Since then, the spread of CQ-resistance has been unrelenting, and currently, CQ-resistance is almost synonymous with P. falciparum [10]. In response to CQ-resistance, antifolate combination drugs were introduced. The best known and most widely used is the combination of sulfadoxine and pyrimethamine (SP) the latter being a well-known antimalarial drug often used on its own. However, pyrimethamine use had already selected resistant $P$. falciparum parasites within one year of its introduction [13]. SP combination therapy was introduced in the 1960's but resistant parasites quickly appeared in Southeast Asia, and spread rapidly to Africa [14].

Failure of $P$. falciparum clinical treatment resulting from parasite resistance to all current antimalarial drugs has placed the new generation of drugs, called artemisinin-based combination therapies (ACTs) at the forefront of malaria control programs [15]. The rationale for ACTs is to combine a fast-acting drug (artemisinin (ART) derivative), with a partner drug with long half-life, such as mefloquine, amodiaquine, piperaquine, pyrimethamine/sulfadoxine or lumefantrine, in order to achieve rapid and effective parasite clearance and to avoid the development of resistance to ART [16]. However, resistance to the partner drug is common, and decreased efficacy to ART derivatives themselves due to resistance is already emerging [3]. The development of resistance mutations may be a rare occurrence; a spontaneous mutation may occur only once in several million parasites. Nevertheless, once it has occurred, it can be selected and disseminated. Consequently, new chemical entities that may overcome the mechanisms of resistance to currently used antimalarial drugs are in urgent demand.

\section{Amazonian Plants: Sources of New Antimalarial Drugs Leads}

A pioneer attempt to apply the scientific method to study the pharmaceutical properties of the plants from Amazonas State, Brazil was performed by the physician and naturalist Alfredo da Matta [17], whose work is still a valuable reference and starting point to research in the field. As expected in a place with such a high biodiversity, many others have been following his path, by exploring the plants used with medicinal purposes by the native communities [18-20]. Among the rural and riverine populations that inhabit the region, a great variety of plant families, such as Fabaceae, Arecaceae, Zingiberaceae and Lamiaceae, have been used to prevent and treat a wide variety of symptoms and 
diseases $[19,20]$. The recent discovery of plants with considerable antibacterial activity $[21,22]$ and the repellent, larvicidal and mosquitocidal properties of plant essential oils and extracts are useful for the control of mosquito vectors of malaria and other tropical diseases and demonstrate the potential of the regional plant biodiversity $[23,24]$ as source for new active compounds, much of which has yet to be explored.

Plants produce useful chemicals for control and treatment of Plasmodium spp. that cause human malaria [25]. Historically, quinine is the most important natural product used to treat malaria. Quinine is a constituent of the traditionally used bark of Cinchona spp. and was isolated for the first time in the early 19th century. Synthetic quinoline antimalarials were developed during the 20th century based on knowledge of quinine's structure [26,27]. In the 1970's, the natural product artemisinin was isolated by Chinese scientists from the traditionally used antimalarial species Artemisia annua L.. Today, artemisinin is isolated from A. annua on an industrial scale. Semi-synthetic derivatives containing the intact 1,2,4-trioxane antimalarial chromophore moiety are prepared from artemisinin in simple reaction sequences [27]. The ACTs that have been introduced in the past two decades contain a synthetic quinoline antimalarial (a phytochemical mimic) and an artemisinin derivative (derived directly from an isolated phytochemical) [16]. As has been emphasized, traditionally used plants are the sources of the most important drugs in the current therapeutic arsenal for combating malaria.

\section{Field Installed Capacity and Recent Findings from the Manaus Drug Discovery Group and Others}

Based on the concept that the next generation of antimalarial drugs may also originate from plants used in traditional medicine, a group of collaborators from the Tropical Medicine Foundation Dr. Heitor Vieira Dourado (FMT-HVD), the Brazilian State-owned Agronomic and Husbandry Research Company (Embrapa), the Federal University of Amazonas (UFAM) and the Federal University of Rio Grande do Norte (UFRN) under the leadership of the National Institute for Amazon Research's (INPA's) Laboratory of Amazonian Active Principles (LAPAAM) has focused on studies on the chemical composition and biological activity of antimalarial plants from the Amazon. Table 1 summarizes information on the chemical composition of plants from the Amazon region.

Several antimalarial phytochemicals may be isolated on gram or multi-gram scales thus potentiating their pharmacological study. The quassinoids neosergeolide and isobruceine B (Figure 1) have each been isolated from the stems and roots of the caferana plant (Picrolemma sprucei) on gram scales using a multi-stage extraction, chromatography and recrystallization sequence [28]. In other work, 4-nerolidylcatechol (4-NC, Figure 1) was readily isolated on a multi-gram scale from the roots of Piper peltatum L. (syn. Pothomorphe peltata Miq.) by straightforward extraction-chromatography. Interestingly, 4-NC makes up $>5 \%$ of the dry weight of $P$. peltatum roots [29] and $P$. peltatum can be cultivated in the Brazilian Amazon where its roots produce $c a .27 \mathrm{~kg}$ of 4-NC per hectare [30,31], thus allowing the use of 4-NC in industrial applications. 
Table 1. Amazonian antimalarial plants and their antiplasmodial chemical components.

\begin{tabular}{|c|c|c|c|c|c|c|c|c|}
\hline Plant species & Family & Common name & Collection place & Part used & Active component & $\mathrm{IC}_{50}(\boldsymbol{\mu M})$ & $P f$ strain & Source \\
\hline $\begin{array}{l}\text { Aspidosperma desmanthum } \\
\text { Benth. ex Müll. Arg. }\end{array}$ & Apocynaceae & araracanga & Brazil & bark & aspidocarpine & 0.019 & K1 & {$[29,32]$} \\
\hline Aspidosperma ulei Markgr. & Apocynaceae & & Brazil & root bark & uleine, olivacine & $1.2-3.7$ & $\mathrm{~K} 1,3 \mathrm{D} 7, \mathrm{~W} 2$ & [33-35] \\
\hline Aspidosperma vargasii A. DC. & Apocynaceae & amarelão & Brazil & bark & ellipticine & $0.073-0.81$ & $\mathrm{~K} 1,3 \mathrm{D} 7$ & {$[29,33]$} \\
\hline Carapa guianensis Aubl. & Meliaceae & andiroba & Peru & seed/flower oil & $\begin{array}{l}\text { gedunins, an andirobin, } \\
\text { mexicanolides, phragmalin-type } \\
\text { limonoids (andirolides) }\end{array}$ & $2.5-15$ & FCR-3 & {$[36]$} \\
\hline Moronobea coccinea Aubl. & Clusiaceae & manniballi & French Guiana & latex & $\begin{array}{l}\text { polyprenylated acylphloroglucinols, } \\
\text { isogarcinol,cycloxanthochymol, } \\
\text { garcinol }\end{array}$ & $2.1-37$ & $\mathrm{FcB} 1$ & {$[37]$} \\
\hline Picrolemma sprucei Hook. f. & Simaroubaceae & caferana & Brazil & root, stem & isobrucein $\mathrm{B}$, neosergeolide & $0.002-0.008$ & $\mathrm{~K} 1$ & {$[29,38]$} \\
\hline Piper peltatum $L$. & Piperaceae & caapeba & Brazil & $\begin{array}{l}\text { root, leaf, } \\
\text { flowering part }\end{array}$ & 4-nerolidylcatechol & 0.67 & $\mathrm{~K} 1$ & {$[29]$} \\
\hline Quassia amara $\mathrm{L}$. & Simaroubaceae & $\begin{array}{l}\text { quinquina de } \\
\text { Cayenne }\end{array}$ & French Guiana & fresh leaf & simalikalactone D, simalikalactone E & $0.010-0.068$ & $\begin{array}{l}\text { FcB1, F32, } \\
\text { W2 }\end{array}$ & {$[39,40]$} \\
\hline $\begin{array}{l}\text { Rheedia acuminata (Ruiz \& } \\
\text { Pavon) Planchon \& Triana }\end{array}$ & Clusiaceae & $\begin{array}{l}\text { cerillo, botoncillo, } \\
\text { caraño }\end{array}$ & French Guiana & root bark & $\begin{array}{l}\text { prenylated xanthones, polyprenylated } \\
\text { acylphloroglucinols }\end{array}$ & $3.2-15$ & $\mathrm{FcB} 1$ & {$[37]$} \\
\hline Simaba orinocensis Kunth & Simaroubaceae & & Peru & root bark & orinocinolide, simalikalactone D & $0.0063-0.018$ & D6, W2 & [41] \\
\hline Tabebuia incana A.H. Gentry & Bignoniaceae & pau d'arco & Brazil & bark & $\begin{array}{l}5 \& \text { 8-hydroxy hydroxyethyl } \\
\text { naphtho[2,3-b]furan-4,9-diones }\end{array}$ & 0.67 & $\mathrm{FcB} 2$ & {$[42,43]$} \\
\hline $\begin{array}{l}\text { Tachia grandiflora Maguire \& } \\
\text { Weaver }\end{array}$ & Gentianaceae & caferana & Brazil & leaf & amplexine (djalonenol) & 35 & W2 & {$[44,45]$} \\
\hline Tapirira guianensis Aubl. & Anacardiaceae & piojo & French Guiana & bark & cyclic alkyl polyols & $4.7-5.4$ & $\mathrm{~F} 32, \mathrm{FcB} 1$ & {$[46]$} \\
\hline Zanthoxylum. rhoifolium Lam & Rutaceae & tachuelo & French Guiana & trunk bark & $\begin{array}{l}\text { avicine hydroxide, nitidine hydroxide, } \\
\text { fagaridine }\end{array}$ & $<0.27-38$ & FCB1 & {$[47]$} \\
\hline
\end{tabular}


Figure 1. Molecular structures of antiplasmodial substances found in Amazonian plants exhibiting submicromolar $\mathrm{IC}_{50}$ values against Plasmodium falciparum in vitro and/or significant in vivo activity in rodent malaria models.

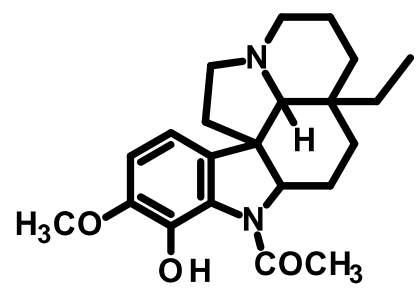

aspidocarpine

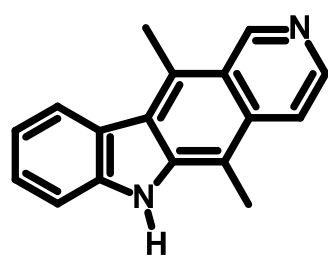

ellipticine

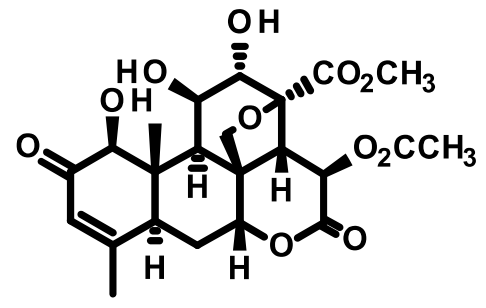

isobruceine B

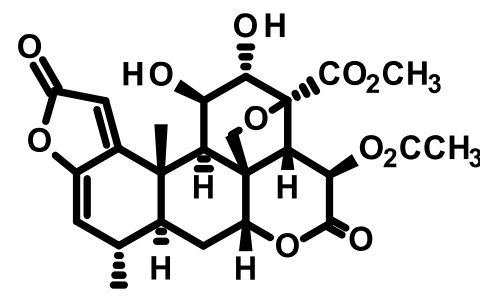

neosergeolide

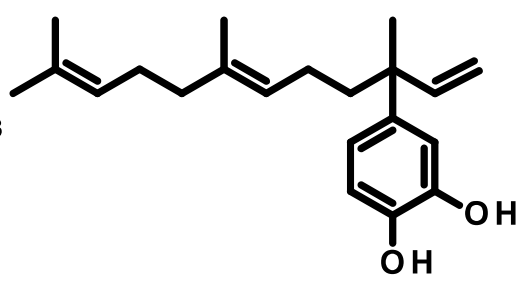

4-nerolidylcatechol

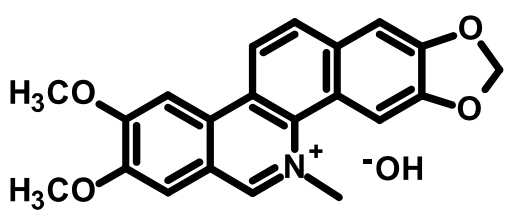

nitidine hydroxide

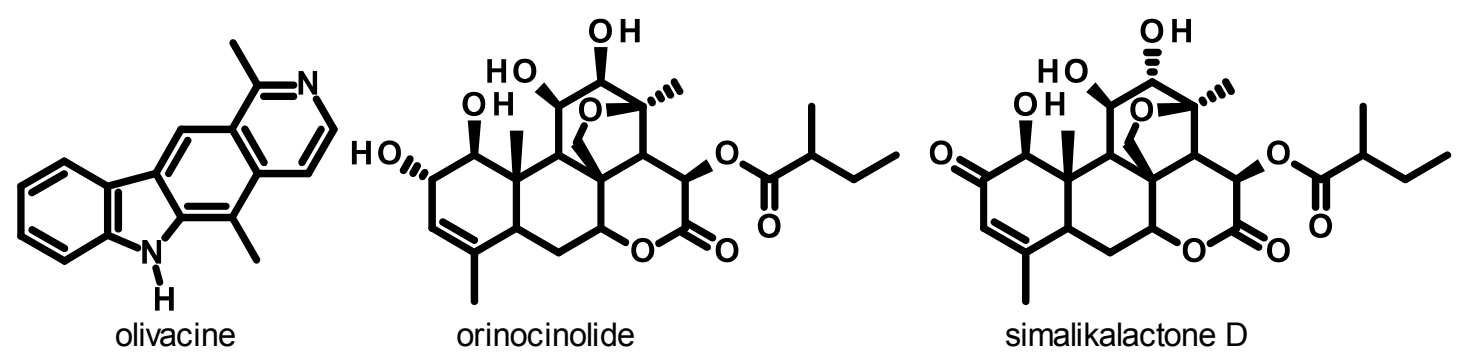

Hyphenated and other analytical methods have been used to determine isobrucein B and neosergeolide in caferana (Picrolemma sprucei) infusions [28,48], 5 and 8-hydroxy-2-(1-hydroxyethyl)naphtho[2,3-b]furan-4,9-dione concentrations in pau d'arco (Tabebuia incana A.H. Gentry) bark infusions[42] and 4-NC in Piper peltatum root infusions [30]. UPLC-ESI-MS analysis of the bark infusions of 8 Aspidosperma spp. from Manaus, Brazil revealed that only A. vargasii contained ellipticine and 2-methyl-1,2,3,4-tetrahydroellipticine [49].

LAPAAM in collaboration with others has been actively screening plant extracts for antimalarial activity. Since 2007, in vitro testing for antimalarial activity by LAPAAM/FMT-HVD has been based on direct counting the number $P$. falciparum in at least 1,000 erythrocytes on thick blood smears using optical microscopy. Several methods (ELISA and tritiated hypoxanthine) are being adopted by INPA to increase screening capacity of plant extracts in the future. Several infusions prepared from carapanaúba tree (Aspidosperma spp.) bark collected in the region around Manaus exhibited strong in vitro inhibition against Plasmodium falciparum $\mathrm{K} 1$ strain [32]. In other work, $\mathrm{MeOH}$ extracts of acariquara branca (Geissospermum argenteum) from Roraima State were also active $\left(\mathrm{IC}_{50}=4.6 \mu \mathrm{g} / \mathrm{mL}\right.$ ) against the $\mathrm{K} 1$ strain of $P$. falciparum in vitro. However, acariquara vermelha (Minquartia guianensis) extracts were inactive $\left(\mathrm{IC}_{50}>50 \mu \mathrm{g} / \mathrm{mL}\right)$ [50]. $\mathrm{CHCl}_{3}$ fractions obtained from root $\mathrm{MeOH}$ and leaf EtOH extracts of the caferana plant (Tachia grandiflora Maguire \& Weaver) inhibited P. falciparum $\left(\mathrm{IC}_{50}=11\right.$ and $36 \mu \mathrm{g} / \mathrm{mL}$, respectively). Root infusions (500 mg/kg/day) of $T$. grandiflora administered 
orally inhibited (45\%-59\% inhibition) Plasmodium berghei in infected mice [44]. EtOH and $\mathrm{H}_{2} \mathrm{O}$ root extracts and piceatannol and chrysophanol isolated from roots of the mari-mari-da-terra-firme (Cassia spruceana Benth.) [31] were inactive against the K1 strain of P. falciparum [51]. Infusions of Artemisia annua cultivated in different Amazonian ecosystems and in another region of Brazil strongly inhibited the K1 and 3D7 standard strains and Amazonian field isolates of P. falciparum [33].

Several of the isolated phytochemicals in Table 1 and derivatives of these natural compounds exhibit significant in vitro and in vivo antimalarial activity. In a seminal publication by our group, the indole alkaloids aspidocarpine (Figure $1, \mathrm{IC}_{50}=19 \mathrm{nM}$ ) and ellipticine $\left(\mathrm{IC}_{50}=73 \mathrm{nM}\right)$, the quassinoid neosergeolide $\left(\mathrm{IC}_{50}=2.0 \mathrm{nM}\right)$ and 4-NC $\left(\mathrm{IC}_{50}=0.67 \mu \mathrm{M}\right)$ significantly inhibited the $\mathrm{K} 1$ strain of P. falciparum [29]. Neosergeolide (Table 1) is toxic to human leukemia cells in vitro but is not toxic to normal cells [52]. The cytotoxicity parameters of neosergeolide and isobrucein B against normal human cells requires further evaluation. Semi-synthetic derivatives 12-acetylneosergeolide $\left(\mathrm{IC}_{50}=0.22 \mu \mathrm{M}\right)$ and 1,12-diacetylisobrucein $\mathrm{B}\left(\mathrm{IC}_{50}=37 \mu \mathrm{M}\right)$ were much less active in vitro against the $\mathrm{K} 1$ strain of $P$. falciparum than neosergeolide $\left(\mathrm{IC}_{50}=7.9 \mathrm{nM}\right)$ and isobrucein $\mathrm{B}\left(\mathrm{IC}_{50}=2.1 \mathrm{nM}\right)$ from which these derivatives were prepared [28].

Other important natural products from Amazonian plant sources are also presented in Table 1. One of the most significant is the quassinoid simalikalactone D which has been isolated from Simaba guianensis, S. orinocensis and Quassia amara among other species of Simaroubaceae. Its antiplasmodial activity was first described in 1993 and it was repeatedly shown to present high antiplasmodial activity against Plasmodium falciparum strains [53]. Simalikalactone D was also found to have a median effective dose $\left(\mathrm{ED}_{50}\right)$ of $3.7 \mathrm{mg} / \mathrm{kg} /$ day against the rodent malaria parasite Plasmodium yoelii yoelii, highlighting its therapeutic potential in vivo [39].

In other work, limonoids from Carapa guianensis have been shown to have significant in vitro antiplasmodial activity against $P$. falciparum (Table 1), with no selective toxicity against mouse mammary tumor cells [36]. The cytotoxicity of these limonoids should be studied further against normal human cell lines. Furthermore, given the in vitro and in vivo antimalarial potential demonstrated by the limonoid gedunin and its semi-synthetic derivatives, it is important to study the activity of $C$. guianensis gedunin structurally-related isolates in in vivo rodent malaria models.

The significant in vitro antiplasmodial activity of ellipticine (Figure 1) against $P$. falciparum has been independently confirmed [45]. Also, some simple derivatives of ellipticine exhibit greater in vitro activity than ellipticine against $P$. falciparum [54]. At LAPAAM, derivatives of ellipticine have been prepared by direct reactions on ellipticine, however none of these simple ellipticine derivatives exhibited greater in vitro inhibition against $P$. falciparum than ellipticine itself [49]. In a comparative study, we found that ellipticine $\left(\mathrm{IC}_{50}=0.35-0.81 \mu \mathrm{g} / \mathrm{mL}\right)$ exhibited greater in vitro activity against the $\mathrm{K} 1$ and 3D7 strains of P. falciparum in general than its natural structural isomer, the indole alkaloid olivacine (Figure $1 \mathrm{IC}_{50}=1.2-1.4 \mu \mathrm{g} / \mathrm{mL}$ ) and greater in vitro activity than the indole alkaloid cryptolepine $\left(\mathrm{IC}_{50}=0.80-0.91 \mu \mathrm{g} / \mathrm{mL}\right.$ ) [33]. Cryptolepine exhibited elevated in vitro toxicity to murine macrophages, whereas ellipticine and olivacine exhibited low toxicity to macrophages and selectivity indices $>2800$. Also, ellipticine ( $10 \mathrm{mg} / \mathrm{kg} /$ day) administered orally or subcutaneously for 4 days was the most active compound tested. It significantly inhibited $P$. berghei in mice (inhibition of 70\%-77\% versus non-treated controls) and led to mean survival times (MST) of 27-29 days for infected mice. At $50 \mathrm{mg} / \mathrm{kg} /$ day, ellipticine exhibited comparable in vivo activity to that of the positive 
control substance chloroquine. Olivacine administered orally was also a highly effective inhibitor of $P$. berghei in mice at $\geq 50 \mathrm{mg} / \mathrm{kg} /$ day providing long MSTs [33]. Ellipticine, olivacine and similar highly planar antiplasmodial compounds may inhibit $P$. falciparum growth through a parasite-specific mechanism-involving blockage of the formation of hemozoin (malaria pigment) through formation of stable complexes with heme in the parasite digestive vacuole [55]. We believe that ellipticine and related structural isomer olivacine may be important prototypes for the development of a new class of indole alkaloid antimalarials. More derivatives and analogs of ellipticine should be screened for in vitro and in vivo antiplasmodial activity to establish SAR parameters and optimal structures.

We further investigated the in vitro and in vivo antimalarial activity of 4-NC and also that of semi-synthetic derivatives of 4-NC. We characterized their activity against the $\mathrm{K} 1\left(\mathrm{IC}_{50}=1.9 \mu \mathrm{M}\right)$ and $3 \mathrm{D} 7\left(\mathrm{IC}_{50}=6.7 \mu \mathrm{M}\right)$ strains (chloroquine resistant and non resistant strain, respectively) and two Amazonian field strains $\left(\mathrm{IC}_{50}=0.16-2.6 \mu \mathrm{M}\right)$ of $P$. falciparum in vitro and against $P$. berghei in mice. In vivo suppression of $P$. berghei in the 4-day suppressive test was observed by oral administration (60\%-63\% on days 5 and 7 after infection) and by subcutaneous administration $(61 \%$ on day 7 after infection) at doses of $600 \mathrm{mg} / \mathrm{kg} /$ day. Also, despite low activity against $P$. berghei in vivo, after ingesting 4-NC, the blood serum of healthy mice was quite active in vitro against $P$. falciparum [56]. $O$-mono and $O, O$-disubstituted semi-synthetic derivatives of 4-NC were prepared and found to inhibit $\left(\mathrm{IC}_{50}=0.67-23 \mu \mathrm{M}\right)$ the $\mathrm{K} 1$ strain of $P$. falciparum in vitro [38]. These derivatives are more stable than 4-NC and exhibit significant antioxidant activity [57]. Importantly, the $O, O$-diacetyl derivative of 4-NC at oral doses of $10-25 \mathrm{mg} / \mathrm{kg} /$ day in the 4-day suppressive test inhibited $P$. berghei in mice by $67 \%-70 \%$ on days 5 and 7 , making this derivative $c a$. 60 times more active than 4 -NC (Rocha e Silva, Pohlit et al. unpublished data). Many terpenes from plants exhibit activity against Plasmodium spp. [25,58] and it is believed that the inhibition by 4-NC and its derivatives is due in part to the 15 carbon terpene nerolidyl side-chain common to these compounds (and the antioxidant properties of 4-NC and derivatives). There is experimental evidence that $O, O$-diacetyl 4-NC, like many terpenes found in plants, inhibits the synthesis of terpenoid-containing metabolites in Plasmodium falciparum (Rocha e Silva, Katzin, Pohlit et al. unpublished data). In the future, more derivatives of 4-NC should be synthesized on gram-scales for evaluation of their in vivo antimalarial properties in rodent models, as well as toxicological evaluation necessary for further development.

In conclusion, we envisage that the plant-derived compounds highlighted above hold great promise as effective antimalarials. However, from a drug development perspective there are several gaps that need to be addressed before these compounds are considered for clinical development. Further studies on their pharmacokinetic properties, namely on absorption, distribution, metabolism, excretion and toxicity (ADMET) are desirable in order to best understand the steps required for chemical modifications towards the synthesis of analogues with improved properties. The synthesis of analogues with enhanced efficacy would also benefit from in-depth studies on the mechanisms of action of these compounds. This information would provide important biochemical clues about drug-target affinities, which would pave the way for the chemical modifications required for improved potency. The route of drug administration in vivo should be considered more often, as there may be variable pharmacokinetic outcomes that will impact on the drug's efficacy depending on the drug's entry route. Finally, if the above parameters are carefully articulated it may be possible and highly desirable, that the in vivo 
potency of these compounds in experimental models may improve by 10 to 100 -fold, making them serious candidates for the next steps of drug development.

\section{New Generation Antimalarials: Desirable and Essential Characteristics}

New antimalarial drug leads should be active against all known malaria parasites that infect humans (P. falciparum, P. vivax, P. malariae, P. ovale and P. knowlesi) [1,59]. Differences in the biology and life cycles of these species can make this a challenging requirement. New drugs should selectively affect Plasmodium spp. while exhibiting tolerable toxicity profiles in humans. Preferably, these compounds should target Plasmodium spp. via parasite-specific modes of action involving molecular targets and organelles found exclusively in these protozoans [60].

Many common antimalarials were developed to be effective against blood stages of Plasmodium spp. New antimalarial drug leads should ideally be active against blood stages of diverse Plasmodium spp. and block transmission of gametocytes of Plasmodium spp. from humans to female Anopheles spp. mosquitos (malaria vectors) during blood meals (transmission-blocking activity). Also, new chemical entities are desirable that inhibit Plasmodium spp. development prior to or in the liver stage (prophylaxis) [1].

\section{Drug Discovery for P. falciparum: The Path to Appropriate Drug-Sensitive Assays}

The first in vitro test to assess $P$. falciparum drug-sensitivity was developed in 1968 by Rieckmann et al. [61] and consisted in evaluating parasite development from early ring stage to mature schizonts. After $24 \mathrm{~h}$ of incubation with or without drugs (controls), schizonts were counted in relation to the total number of erythrocytes on thick blood smears prepared from the cultured samples [61]. This technique known as 'macrotest' was capable of distinguishing between chloroquine-sensitive and resistant parasite isolates [61]. The schizont maturation test was improved after the establishment of the continuous culture in 1976 and the 'microtest' developed still remains one of the most common techniques for the assessment of drug sensitivity in vitro [62].

This schizont maturation assay is relatively simple to perform. It requires no expensive equipment. It is, however, a labor-intensive procedure and it needs highly trained microscopists [63]. Importantly, this test might also result in misinterpretation of data, as drugs that delay parasite growth might give the same results as drugs that completely inhibit the parasite development [63].

Soon after the introduction of continuous in vitro cultivation of $P$. falciparum over 30 years ago [64], several methodologies were developed to assess P. falciparum growth in vitro. Later, standardizing of antimalarial drug screening was achieved. Typically, synchronized parasites at ring stage are cultured in the presence of different concentrations of test compound or medium (control). After one schizogonic cycle $(48 \mathrm{~h})$, parasite growth is determined by different methods and $\mathrm{IC}_{50}$ values can be assessed by linear regression analyses of the linear segments of the dose-response curves. Alternatively, unsynchronized cultures or more hours of incubation can be employed [63].

The oldest and also the most low cost method for assessment of Plasmodium falciparum growth in vitro is counting giemsa-stained parasites by light microscopy (the World Health Organization standard method). Although simple, this technique is time-consuming and relies on well-trained microscopists. It allows for the testing of only a small number of compounds in a given period of time. 
To overcome those limitations, tritiated hypoxanthine uptake by parasites has been widely employed [65]. Hypoxanthine is taken up by the parasite as part of purine salvage and DNA synthesis that are essential for parasite development and multiplication. Although highly reliable, this standard method is expensive and uses radioactive materials with limited availability, safety, and with a strict disposal regulation in mostly developing countries $[63,66]$.

$P$. falciparum development can also be determined by means of the enzymatic activity of pLDH (parasite lactate dehydrogenase). pLDH is a terminal enzyme in the glycolysis pathway of the malaria parasite. In the pLDH assay, nitroblue tetrazolium is reduced forming a blue formazan product that can be measured by spectrophotometry [67]. This assay requires initial parasite densities of $1 \%-2 \%$ and therefore, its use is limited [63]. A new pLDH-based assay that measures pLDH levels in a double-site enzyme-linked LDH immuno-detection (DELI) assay has been developed. This method is considered to be more sensitive [68] than previous methods and therefore is applicable in field conditions. Another ELISA-based test relies on the measurement of a histidine and alanine-rich protein produced by $P$. falciparum in the course of its growth and multiplication (HRP2 assay) [69]. The HRP2 assay uses a longer culture time than most other assays ( $72 \mathrm{~h}$ instead of $48 \mathrm{~h}$ ) and parasite growth is assessed by measuring the production of HRP2 in a simple, commercially available, double-site sandwich, ELISA test kit or essentially any ELISA that is specific to HRP2.

Many nucleic acid dyes (SYBR Green I, YOYO-1, propidium iodide, acridine orange, hydroethidine, Hoechst, DAPI) have been used to assess antimalarial activity of a variety of compounds. These methods take advantage of the fact that human erythrocytes lack DNA and RNA [66]. Many methods are based on the use of the nucleic acid dyes and, have now been used in high throughout put screening (HTS). These methods vary from a simple fluorescence-based parasite proliferation assay [70] to a nuclear dye-based high- throughput confocal imaging assay [71]. Flow cytometry is another method that uses nucleic acid dyes and has the advantage that appropriate gating can also allow one to distinguish different parasite erythrocytic stages [72,73]. Transfected parasites expressing nucleic acid dyes appear to be a useful model for drug screening despite the greater complexity of this method. Green fluorescent protein (GFP)-recombinant Plasmodium parasites have been successfully used in antimalarial screening [74]. Aside from assays using nucleic acid dyes, transfected parasites expressing firefly luciferase are another approach for assaying antimalarial drugs. This method generates similar sensitivity results to radiolabeled hypoxanthine uptake $[75,76]$.

Lastly, to accelerate drug discovery we have recently established a high-throughput high-content assay to monitor the intraerythrocytic asexual cycle of $P$. falciparum. The assay consists of imaging a synchronized population of parasites during the erythrocytic cycle and determining through the size of fluorescently labeled organelles the developmental age of the parasite. An automated algorithm analyzes the images, differentiating between rings, trophozoites and schizonts. This method allows for high throughput screening in an unbiased way. It permits the determination of the stage(s) in the erythrocytic cycle in which the drug is active. It is now being used to investigate the mechanism of action of novel antimalarials (Freitas Junior and Ayong, unpublished data).

It is important to note that the in vitro techniques based on $P$. falciparum cultures do not provide information on potential in vivo metabolism of phytoconstituents that may be required as an activation step of prodrug antimalarial substances. Also, pharmacodynamic, pharmacokinetic and toxicologic data are not forthcoming from in vitro studies. Phytoconstituents exhibiting promising in vitro 
antimalarial activity must therefore be evaluated for in vivo antimalarial activity against $P$. berghei, P. chabaudi, P. yoelii or other rodent or animal models of malaria [77]. In vivo studies are sometimes difficult to perform given that larger quantities of isolated natural products are frequently not available. Also, government restrictions adopted in many countries to avoid a deliberate use of a large number of animals are also a factor to be taken in consideration. However, in vivo studies are essential for the development of antimalarial drugs from phytochemicals.

\section{Plasmodium vivax Malaria: Neglected and Misinterpreted}

Plasmodium vivax threatens 2.48 billion people worldwide and infects between 130 and 435 million people per year [78,79]. P. vivax has some characteristics that make it harder to control than $P$. falciparum, including the existence of dormant liver forms (hypnozoites) that cause relapses and the relatively early presence of circulating gametocytes [80]. Accordingly, $P$. vivax is becoming proportionately a more common cause of malaria in some areas where falciparum malaria control has been strengthened [81-83]. In Brazil, for example, vivax malaria became predominant around 1990, when control measures were intensified [84]. In 2011, Brazil has reported more than 247 thousand malaria cases (due to P. vivax, P. falciparum and P. malariae), with $87 \%$ of them attributed to P. vivax [85].

The dogma that classified $P$. vivax infection as a benign disease is now largely discredited. This is due to increasing reports of severe disease caused by this parasite combined with reassessment of the importance of the morbidity and mortality associated with this parasite to public health. Indeed, there are a great number of studies focusing on severe manifestations of $P$. vivax worldwide [86-100]. This former misconception has contributed to long-term neglect of $P$. vivax infections. One of the consequences of this neglect has been that little effort towards research and development of new anti- $P$. vivax drugs has been made [101-103].

Treatment of $P$. vivax infections in most endemic areas is based on chloroquine (CQ), used alone or in combination with primaquine. The latter is the only approved antimalarial drug that acts on Plasmodium spp. liver stages (hypnozoites), preventing relapses [85]. P. vivax CQ-resistance was reported in Papua New Guinea in 1989 [104], almost thirty years after the emergence of CQ-resistance in P. falciparum [105]. To date, there is clear evidence of the existence of CQ-resistant $P$. vivax in many other countries, including those of northern South America [106-108]. The high prevalence of CQ-resistant $P$. vivax in some areas $[106,109]$ has been hypothesized as an important contributor to the high risk of severe vivax disease [88] and contributes to the overall morbidity.

\section{Drug Discovery for P. vivax: The Next Step Forward}

$P$. vivax infection is a neglected disease for which few drug susceptibility studies have been performed [103]. Indeed, drug susceptibility assays are a complicated undertaking as long term in vitro culture systems for the erythrocytic forms of this parasite have not yet been developed. This technological barrier precludes the implementation of $P$. vivax drug discovery programs. Efforts towards discovery, characterization and proper validation of $P$. vivax drug targets are significantly hampered. Knowledge of these molecular targets is necessary for the development of specific biochemical assays. Thus, medium to large scale screening campaigns of compound libraries against 
whole $P$. vivax parasites are not possible. Such campaigns would require robust and reproducible assays using lab-adapted $P$. vivax parasites. From the clinical drug development perspective, major candidate molecules against $P$. falciparum have been proposed to be tested first in proof-of-concept studies using $P$. vivax-infected patients, since this infection is considered to be more benign and therefore, phase II studies would not submit patients to higher risk of severe disease. However, the increase in the report of severe vivax cases worldwide makes this approach somehow questionable.

In this scenario, the pragmatic solution is to continue to use $P$. falciparum as a surrogate model for vivax antimalarial drug discovery (see section on drug-sensitivity assays). Historically, clinical use of the same drugs to treat all human malarias has provided experience that in spite of biological differences, $P$. falciparum is a suitable model for in vitro drug testing and drug discovery for $P$. vivax malaria. However, reports in the past years have challenged this belief. For example, it has been suggested that $P$. vivax is intrinsically resistant to antifolates [110], although this has been contested by more recent data [111]. Russell et al. demonstrated that $P$. vivax trophozoites are considerably more resistant to chloroquine than $P$. falciparum trophozoites in ex vivo maturation assays, even when parasites were sampled from patients from endemic areas associated with reasonable chloroquine therapeutic sensitivity [112]. Additionally, experimental data suggest that mechanisms of resistance to chloroquine differ between P. falciparum and P. vivax [111,113,114].

The ex vivo schizont maturation test has been successfully employed over the past years to assess levels of antimalarial resistance and test novel drug candidates against $P$. vivax [115-118]. This assay consists of visually monitoring the erythrocytic development of ring and young trophozoites into mature schizonts, and drugs that are able to inhibit the maturation process in a dose-dependent manner are considered active against $P$. vivax. However, the test results can be influenced by the initial blood stage composition and the speed of maturation of the clinical isolate [112,116]. In any case, though it is not a high throughput method, the $48 \mathrm{~h}$ short-term in vitro culture of $P$. vivax may serve at the moment as a reasonable screening tool in order to evaluate antimalarials against this species' blood stages.

\section{Hypnozoite Drug Tests: The Greatest Challenge}

To achieve malaria eradication it is paramount to have drugs effective against hypnozoites, the mysterious dormant liver stage that causes relapses in $P$. vivax and $P$. ovale malaria [119]. To date, few in vitro hypnozoite assays have been developed for both $P$. vivax and the monkey malaria parasite P. cynomolgi [120-123]. However it remains to be shown whether these assays can be used for routine drug discovery as they are technically challenging, and can only be carried out in facilities where insectaries are available. Also, in the case of hypnozoites, as opposed to blood stages, the use of $P$. falciparum as surrogate model is unsuitable, as it cannot produce hypnozoites. In the Amazon, in some research centers, the possibility of inducing experimental $P$. vivax in vitro liver stage infection (concomitant availability of infected patient-derived gametocytes and insectaries with An. aquasalis in Manaus, Brazil or An. albimanus in Cali, Colombia) paves the way for future studies, which are not possible outside the endemic area. 


\section{Perspectives}

In the future, we believe that several substances derived from Amazonian plants could be evaluated for in vitro activity against clinical samples of $P$. vivax in limited culture and for transmission-blocking and prophylactic activity of $P$. berghei in different laboratory models. As we mentioned, ellipticine, its derivatives and 4-nerolidylcatechol derivatives have potential as lead compounds for the development of new antimalarial drugs.

$P$. vivax has tended to be neglected despite recent reports indicating that severe vivax malaria may be underestimated. Moreover, there is evidence that $P$. vivax has developed resistance to chloroquine, sulfadoxine + pyrimethamine [124] and primaquine [125]. There is now a priority to also put emphasis on $P$. vivax-directed research. Thus, the use of novel screening technologies, most notably image-based assays that can distinguish between the live and dead parasites and between rings, trophozoites and schizont stages (Freitas-Junior and collaborators, unpublished data), and cytometry-based high-content screening with probes that can identify and quantitate mature blood stages in low parasitemia [126-128] hold promise if they can be coupled to the schizont maturation test. Recent work featuring an automated high content screening assay that measured parasite size and consequently schizont growth and maturation of P. yoelii liver stage [129] demonstrated that this approach is viable. A rational approach, given the variable nature of the ex vivo maturation test, would be to have antimalarial drugs tested against lab adapted $P$. falciparum strains to select only compounds able to block the intraerythrocytic development and maturation of asexual forms. In this way, the likelihood of finding compounds active against clinical isolates in ex vivo maturation tests would increase. Although more challenging, similar strategies could be employed to selected drug leads in P. vivax-infected hepatocytes.

\section{Concluding Remarks}

Traditionally-used Amazonian plants are important for the discovery of new antimalarial leads against $P$. falciparum and P. vivax. The success of this drug discovery effort depends on the availability of increased capacity screening facilities in malaria endemic areas, which in turn are very often resource-limited areas. Therefore, solid drug discovery programs for $P$. vivax depend on the establishment of multidisciplinary research networks involving several institutions and expertises. Also, considerable investments are needed to equip laboratories in endemic regions to develop novel assays that can enable the screening of novel compounds against the $P$. vivax parasite.

\section{Acknowledgements}

This work received financial support from Fundação de Amparo a Pesquisa do Estado de São Paulo (FAPESP, Brazil), Fundação de Amparo a Pesquisa do Estado do Amazonas (FAPEAM, Brazil; PRONEX), Conselho Nacional de Desenvolvimento Científico e Tecnológico (CNPq, Brazil; National Malaria Network, Bionorth Network), Instituto Nacional de Tecnologia em Vacinas (CNPq-FAPEMIG, Brazil) and Instituto Nacional de Tecnologia em Doenças Negligenciadas (CNPq, Brazil). S.C.P.L. is sponsored by FAPESP fellowship. L.F.R.S. was supported by a PCI/INPA/MCTI/CNPq fellowship. A.M.P. M.V.G.L. and F.T.M.C. are CNPq fellows. F.T.M.C. is enrolled at the Programa Estratégico de Ciência, Tecnologia \& Inovação nas Fundações Estaduais de Saúde (PECTI/AM Saúde) from 
Fundação de Amparo à Pesquisa do Estado do Amazonas (FAPEAM, Brazil). P.C. is a fellow of CAPES/PVE in Brazil.

\section{Conflict of Interest}

The authors declare no conflict of interest.

\section{References}

1. malERA Consultative Group on Drugs. A research agenda for malaria eradication: Drugs. PLoS Med. 2011, 8, e1000402.

2. White, N.J. Counter perspective: Artemisinin resistance: Facts, fears, and fables. Am. J. Trop. Med. Hyg. 2012, 87, 785.

3. Phyo, A.P.; Nkhoma, S.; Stepniewska, K.; Ashley, E.A.; Nair, S.; McGready, R.; ler Moo, C.; Al-Saai, S.; Dondorp, A.M.; Lwin, K.M.; et al. Emergence of artemisinin-resistant malaria on the western border of Thailand: a longitudinal study. Lancet 2012, 379, 1960-1966.

4. Milliken, W. Plants for Malaria, Plants for Fever: Medicinal Species in Latin America, A Bibliographic Survey; Royal Botanic Gardens, Kew: Richmond, VA, USA, 1997; p.116.

5. Ruiz, L.; Ruiz, L.; Maco, M.; Cobos, M.; Gutierrez-Choquevilca, A.L.; Roumy, V. Plants used by native Amazonian groups from the Nanay River (Peru) for the treatment of malaria. J. Ethnopharmacol. 2011, 133, 917-921.

6. Vigneron, M.; Deparis, X.; Deharo, E.; Bourdy, G. Antimalarial remedies in French Guiana: a knowledge attitudes and practices study. J. Ethnopharmacol. 2005, 98, 351-360.

7. Bero, J.; Quetin-Leclercq, J. Natural products published in 2009 from plants traditionally used to treat malaria. Planta Med. 2011, 77, 631-640.

8. Deharo, E.; Ginsburg, H. Analysis of additivity and synergism in the anti-plasmodial effect of purified compounds from plant extracts. Malar. J. 2011, 10 (Suppl 1), S5.

9. Andrade-Neto, V.F.; Brandao, M.G.; Nogueira, F.; Rosario, V.E.; Krettli, A.U. Ampelozyziphus amazonicus Ducke (Rhamnaceae), a medicinal plant used to prevent malaria in the Amazon Region, hampers the development of Plasmodium berghei sporozoites. Int. J. Parasitol. 2008, $38,1505-1511$.

10. World Health Organization. Global Report on Antimalarial Drug Efficacy and Drug Resistance: 2000-2010; World Health Organization: Geneva, Switzerland, 2010; p.115.

11. Young, M.D.; Moore, D.V. Chloroquine resistance in Plasmodium falciparum. Am. J. Trop. Med. Hyg. 1961, 10, 317-320.

12. Harinasuta, T.; Migasen, S.; Boonag, D. Chloroquine Resistance in Plasmodium Falciparum in Thailand; UNESCO First Regional Symposium on Scientific Knowledge of Tropical Parasites: Singapore University, Singapore, 1962.

13. Peters, W. Chemotherapy and Drug Resistance in Malaria. 2nd ed.; Academic: London, UK, 1987.

14. Roper, C.; Pearce, R.; Nair, S.; Sharp, B.; Nosten, F.; Anderson, T. Intercontinental spread of pyrimethamine-resistant malaria. Science 2004, 305, 1124.

15. Enserink, M. Combating malaria. Malaria treatment: ACT two. Science 2007, 318, 560-563. 
16. World Health Organization. Roll Back Malaria Dept. Guidelines for the Treatment of Malaria; World Health Organization: Geneva, Switzerland, 2006; p. 253.

17. Da Mata, A.A. Flora Médica Brasiliense. Valer Editora: Manaus, Brazil, 2003.

18. Elisabetsky, E.; Shanley, P. Ethnopharmacology in the Brazilian Amazon. Pharmacol. Therap. 1994, 64, 201-214.

19. Rodrigues, E. Plants and animals utilized as medicines in the Jau National Park (JNP), Brazilian Amazon. Phytother. Res. 2006, 20, 378-391.

20. Santos J.F.; Pagani, E.; Ramos, J.; Rodrigues, E. Observations on the therapeutic practices of riverine communities of the Unini River, AM, Brazil. J. Ethnopharmacol. 2012, 142, 503-515.

21. Suffredini, I.B.; Paciencia, M.L.; Varella, A.D.; Younes, R.N. Antibacterial activity of Brazilian Amazon plant extracts. Braz. J. Infect. Dis. 2006, 10, 400-402.

22. Carneiro, A.L.; Teixeira, M.F.; Oliveira, V.M.; Fernandes, O.C.; Cauper, G.S.; Pohlit, A.M. Screening of Amazonian plants from the Adolpho Ducke forest reserve, Manaus, state of Amazonas, Brazil, for antimicrobial activity. Mem. Inst. Oswaldo Cruz 2008, 103, 31-38.

23. Pohlit, A.M.; Lopes, N.P.; Gama, R.A.; Tadei, W.P.; Neto, V.F. Patent literature on mosquito repellent inventions which contain plant essential oils-A review. Planta Med. 2011, 77, 598-617.

24. Pohlit, A.M.; Rezende, A.R.; Lopes Baldin, E.L.; Lopes, N.P.; Neto, V.F. Plant extracts, isolated phytochemicals, and plant-derived agents which are lethal to arthropod vectors of human tropical diseases-A review. Planta Med. 2011, 77, 618-630.

25. Schmidt, T.J.; Khalid, S.A.; Romanha, A.J.; Alves, T.M.; Biavatti, M.W.; Brun, R.; Da Costa, F.B.; de Castro, S.L.; Ferreira, V.F.; de Lacerda, M.V.; et al. The potential of secondary metabolites from plants as drugs or leads against protozoan neglected diseases-part I. Curr. Med. Chem. 2012, 19, 2128-2175.

26. Achan, J.; Talisuna, A.O.; Erhart, A.; Yeka, A.; Tibenderana, J.K.; Baliraine, F.N.; Rosenthal, P.J.; D'Alessandro, U. Quinine, an old anti-malarial drug in a modern world: role in the treatment of malaria. Malar. J. 2011, 10, 144.

27. Bray, P.G.; Ward, S.A.; O'Neill, P.M. Quinolines and artemisinin: chemistry, biology and history. Curr. Top. Microbiol. Immunol. 2005, 295, 3-38.

28. Pohlit, A.M.; Jabor, V.A. P.; Amorim, R.C. N.; Costa e Silva, E.C.; Lopes, N.P. LC-ESI-MS Determination of Quassinoids Isobrucein B and Neosergeolide in Picrolemma sprucei Stem Infusions. J. Braz. Chem. Soc. 2009, 20, 1065-1070.

29. de Andrade-Neto, V.F.; Pohlit, A.M.; Pinto, A.C.; Silva, E.C.; Nogueira, K.L.; Melo, M.R.; Henrique, M.C.; Amorim, R.C.; Silva, L.F.; Costa, M.R.; et al. In vitro inhibition of plasmodium falciparum by substances isolated from Amazonian antimalarial plants. Mem. Inst. Oswaldo Cruz 2007, 102, 359-365.

30. Pinto, A.C.; Chaves, F.C.; dos Santos, P.A.; Nunez, C.V.; Tadei, W.P.; Pohlit, A.M. Piper peltatum: Biomass and 4-nerolidylcatechol production. Planta Med. 2010, 76, 1473-1476.

31. Pinto, P.S. Estudo químico e atividade biológica de frações do extrato etanólico da raiz de Cassia spruceana Benth. (Leguminosae: Caesalpinioideae). M.Sc. Thesis, Universidade Federal do Amazonas, Manaus, Brazil, 2006.

32. Henrique, M.C.; Nunomura, S.M.; Pohlit, A.M. Indole alkaloids from the bark of Aspidosperma vargasii and A. desmanthum. Quim. Nova 2010, 33, 284-287. 
33. Rocha e Silva, L.F.; Montoia, A.; Amorim, R.C.; Melo, M.R.; Henrique, M.C.; Nunomura, S.M.; Costa, M.R.; Andrade Neto, V.F.; Costa, D.S.; Dantas, G.; et al. Comparative in vitro and in vivo antimalarial activity of the indole alkaloids ellipticine, olivacine, cryptolepine and a synthetic cryptolepine analog. Phytomed. Int. J. Phytother. Phytopharmacol. 2012, 20, 71-76.

34. Dos Santos Torres, Z.E.; Silveira, E.R.; Rocha, E.S.L.F.; Lima, E.S.; de Vasconcellos, M.C.; de Andrade Uchoa, D.E.; Filho, R.B.; Pohlit, A.M. Chemical Composition of Aspidosperma ulei Markgr and Antiplasmodial Activity of Selected Indole Alkaloids. Molecules 2013, 18, 6281-6297.

35. Oliveira, A.B.; Dolabela, M.F.; Póvoa, M.M.; Santos, C.A.M.; Varotti, F.P. Antimalarial activity of ulein and proof of its action on the Plasmodium falciparum digestive vacuole. Malar. J. 2010, doi:10.1186/1475-2875-9-S2-O9.

36. Tanaka, Y.; Sakamoto, A.; Inoue, T.; Yamada, T.; Kikuchi, T.; Kajimoto, T.; Muraoka, O.; Sato, A.; Wataya, Y.; Kim, H.-S.; et al. Andirolides H-P from the flower of andiroba (Carapa guianensis, Meliaceae) Tetrahedron 2012, 68, 3669-3677.

37. Marti, G.; Eparvier, V.; Moretti, C.; Susplugas, S.; Prado, S.; Grellier, P.; Retailleau, P.; Gueritte, F.; Litaudon, M. Antiplasmodial benzophenones from the trunk latex of Moronobea coccinea (Clusiaceae). Phytochemistry 2009, 70, 75-85.

38. Pinto, A.C.; Silva, L.F.; Cavalcanti, B.C.; Melo, M.R.; Chaves, F.C.; Lotufo, L.V.; de Moraes, M.O.; de Andrade-Neto, V.F.; Tadei, W.P.; Pessoa, C.O.; et al. New antimalarial and cytotoxic 4-nerolidylcatechol derivatives. Eur. J. Med. Chem. 2009, 44, 2731-2735.

39. Bertani, S.; Houel, E.; Stien, D.; Chevolot, L.; Jullian, V.; Garavito, G.; Bourdy, G.; Deharo, E. Simalikalactone D is responsible for the antimalarial properties of an Amazonian traditional remedy made with Quassia amara L. (Simaroubaceae). J. Ethnopharmacol. 2006, 108, 155-157.

40. Cachet, N.; Hoakwie, F.; Bertani, S.; Bourdy, G.; Deharo, E.; Stien, D.; Houel, E.; Gornitzka, H.; Fillaux, J.; Chevalley, S.; et al. Antimalarial activity of simalikalactone E, a new quassinoid from Quassia amara L. (Simaroubaceae). Antimicrob. Agents Chemother. 2009, 53, 4393-4398.

41. Muhammad, I.; Bedir, E.; Khan, S.I.; Tekwani, B.L.; Khan, I.A.; Takamatsu, S.; Pelletier, J.; Walker, L.A. A new antimalarial quassinoid from Simaba orinocensis. J. Nat. Prod. 2004, 67, $772-777$.

42. Morais, S.K.R.; Silva, S.G.; Portela, C.N.; Nunomura, S.M.; Quignard, E.L.J.; Pohlit, A.M. Bioactive dihydroxyfuranonaphthoquinones from the bark of Tabebuia incana A.H. Gentry (Bignoniaceae) and HPLC analysis of commercial pau d'arco and certified T. incana bark infusions. Acta Amaz. 2007, 37, 99-102.

43. Pérez, H.; Diaz, F.; Medina, J.D. Chemical investigation and in vitro antimalarial activity of Tabebuia ochracea ssp. neochrysantha. Pharm. Biol. 1997, 35, 227-235.

44. Rocha e Silva, L.F.; Lima, E.S.; Vasconcellos, M.C.; Aranha, E.S. P.; Costa, D.S.; Santos, E.V.M.; Silva, T.C.M.; Morais, S.K.R.; Quignard, E.L.J.; Alecrim, M.G.C.; et al. In vitro and in vivo antimalarial activity and cytotoxicity of extracts, fractions and a substance isolated from the Amazonian plant Tachia grandiflora (Gentianaceae) Mem. Inst. Oswaldo Cruz 2013, 108, 501-507.

45. Pohlit, A.M.; Rocha e Silva, L.F.; Henrique, M.C.; Montoia, A.; Amorim, R.C.; Nunomura, S.M.; Andrade-Neto, V.F. Antimalarial activity of ellipticine. Phytom. Int. J. Phytother. Phytopharmacol. 2012, 19, 1049. 
46. Roumy, V.; Fabre, N.; Portet, B.; Bourdy, G.; Acebey, L.; Vigor, C.; Valentin, A.; Moulis, C. Four anti-protozoal and anti-bacterial compounds from Tapirira guianensis. Phytochem. 2009, 70, 305-311.

47. Jullian, V.; Bourdy, G.; Georges, S.; Maurel, S.; Sauvain, M. Validation of use of a traditional antimalarial remedy from French Guiana, Zanthoxylum rhoifolium Lam. J. Ethnopharmacol. 2006, 106, 348-352.

48. Saraiva Nunomura, R.C.; Pinto, A.C.; Nunomura, S.M.; Pohlit, A.M.; Fernandes Amaral, A.C. Chemical constitutents from stems of Simaba guianensis subesp ecaudata (Cronquist). Quim. Nova 2012, 35, 2153-2158.

49. Montoia, A. Semi-síntese de derivados da elipticina e atividade antimalárica de isolados e infusões de Aspidosperma vargasii. M.Sc. Thesis, Universidade Federal do Amazonas, Manaus, Brazil, 2013.

50. Camargo, M.R.M. Avaliação da Atividade Antimalárica e Antimicrobiana de Geissospermum argenteum e Minquartia guianensis, coletadas em Roraima. M.Sc. Thesis, Universidade Federal de Rondônia, Brazil, 2011.

51. Pinto, P.S.; Rocha e Silva, L.F.; Amorim, R.C.N.; Melo, M.R.S.; Nunomura, S.M.; Pohlit, A.M.Q.N. Phenolic constituents from the roots of Cassia spruceana Benth. (Fabaceae) Quim. Nova 2013, submitted for publish.

52. Cavalcanti, B.C.; da Costa, P.M.; Carvalho, A.A.; Rodrigues, F.A.; Amorim, R.C.; Silva, E.C.; Pohlit, A.M.; Costa-Lotufo, L.V.; Moraes, M.O.; Pessoa, C. Involvement of intrinsic mitochondrial pathway in neosergeolide-induced apoptosis of human HL-60 leukemia cells: the role of mitochondrial permeability transition pore and DNA damage. Pharm. Biol. 2012, 50, 980-993.

53. Cabral, J.A.; McChesney, J.D.; Milhous, W.K. A new antimalarial quassinoid from Simaba guianensis. J. Nat. Prod. 1993, 56, 1954-1961.

54. Passemar, C.; Salery, M.; Soh, P.N.; Linas, M.D.; Ahond, A.; Poupat, C.; Benoit-Vical, F. Indole and aminoimidazole moieties appear as key structural units in antiplasmodial molecules. Phytomed. Int. J. Phytother. Phytopharmacol. 2011, 18, 1118-1125.

55. Chong, C.R.; Sullivan, D.J., Jr. Inhibition of heme crystal growth by antimalarials and other compounds: implications for drug discovery. Biochem. Pharmacol. 2003, 66, 2201-2212.

56. Rocha, E.S.L.F.; Silva Pinto, A.C.; Pohlit, A.M.; Quignard, E.L.; Vieira, P.P.; Tadei, W.P.; Chaves, F.C.; Samonek, J.F.; Lima, C.A.; Costa, M.R.; et al. In vivo and in vitro antimalarial activity of 4-nerolidylcatechol. Phytother. Res. 2011, 25, 1181-1188.

57. Silva Lima, E.; Silva Pinto, A.C.; Nogueira, K.L.; Rocha e Silva, L.F.; Oliveira de Almeida, P.D.; Carvalho de Vasconcellos, M.; Chaves, F.C.; Tadei, W.P.; Pohlit, A.M. Stability and antioxidant activity of semi-synthetic derivatives of 4-nerolidylcatechol. Molecules 2012, 18, 178-189.

58. Mota, M.L.; Lobo, L.T.; Costa, J.M.; Costa, L.S.; Rocha, H.A.; Rocha e Silva, L.F.; Pohlit, A.M.; Neto, V.F. In vitro and in vivo antimalarial activity of essential oils and chemical components from three medicinal plants found in northeastern Brazil. Planta Med. 2012, 78, 658-664.

59. Baird, J.K. Eliminating malaria--all of them. Lancet 2010, 376, 1883-1885.

60. Schrader, F.C.; Barho, M.; Steiner, I.; Ortmann, R.; Schlitzer, M. The antimalarial pipeline-An update. Int. J. Med. Microbiol. 2012, 302, 165-171. 
61. Rieckmann, K.H.; McNamara, J.V.; Frischer, H.; Stockert, T.A.; Carson, P.E.; Powell, R.D. Effects of chloroquine, quinine, and cycloguanil upon the maturation of asexual erythrocytic forms of two strains of Plasmodium falciparum in vitro. Am. J. Trop. Med. Hyg. 1968, 17, 661-671.

62. Rieckmann, K.H.; Campbell, G.H.; Sax, L.J.; Mrema, J.E. Drug sensitivity of plasmodium falciparum. An in vitro microtechnique. Lancet 1978, 1, 22-23.

63. Noedl, H.; Wongsrichanalai, C.; Wernsdorfer, W.H. Malaria drug-sensitivity testing: New assays, new perspectives. Trends Parasitol. 2003, 19, 175-181.

64. Trager, W.; Jensen, J.B. Human malaria parasites in continuous culture. Science 1976, 193, 673-675.

65. Desjardins, R.E.; Canfield, C.J.; Haynes, J.D.; Chulay, J.D. Quantitative assessment of antimalarial activity in vitro by a semiautomated microdilution technique. Antimicrob. Agents Chemother. 1979, 16, 710-718.

66. Aguiar, A.C.; Rocha, E.M.; Souza, N.B.; Franca, T.C.; Krettli, A.U. New approaches in antimalarial drug discovery and development: a review. Mem. Inst. Oswaldo Cruz 2012, 107, 831-845.

67. Makler, M.T.; Ries, J.M.; Williams, J.A.; Bancroft, J.E.; Piper, R.C.; Gibbins, B.L.; Hinrichs, D.J. Parasite lactate dehydrogenase as an assay for Plasmodium falciparum drug sensitivity. Am. J. Trop. Med. Hyg. 1993, 48, 739-741.

68. Druilhe, P.; Moreno, A.; Blanc, C.; Brasseur, P.H.; Jacquier, P. A colorimetric in vitro drug sensitivity assay for Plasmodium falciparum based on a highly sensitive double-site lactate dehydrogenase antigen-capture enzyme-linked immunosorbent assay. Am. J. Trop. Med. Hyg. 2001, 64, 233-241.

69. Noedl, H.; Wernsdorfer, W.H.; Miller, R.S.; Wongsrichanalai, C. Histidine-rich protein II: a novel approach to malaria drug sensitivity testing. Antimicrob. Agents Chemother. 2002, 46, $1658-1664$.

70. Plouffe, D.; Brinker, A.; McNamara, C.; Henson, K.; Kato, N.; Kuhen, K.; Nagle, A.; Adrian, F.; Matzen, J.T.; Anderson, P.; et al. In silico activity profiling reveals the mechanism of action of antimalarials discovered in a high-throughput screen. Proc. Natl. Acad. Sci. USA 2008, 105, 9059-9064.

71. Cervantes, S.; Stout, P.E.; Prudhomme, J.; Engel, S.; Bruton, M.; Cervantes, M.; Carter, D.; Tae-Chang, Y.; Hay, M.E.; Aalbersberg, W.; et al. High content live cell imaging for the discovery of new antimalarial marine natural products. BMC Infect. Dis. 2012, 12, 1.

72. van Vianen, P.H.; Thaithong, S.; Reinders, P.P.; van Engen, A.; van der Keur, M.; Tanke, H.J.; van der Kaay, H.J.; Mons, B. Automated flow cytometric analysis of drug susceptibility of malaria parasites. Am. J. Trop. Med. Hyg. 1990, 43, 602-607.

73. Saito-Ito, A.; Akai, Y.; He, S.; Kimura, M.; Kawabata, M. A rapid, simple and sensitive flow cytometric system for detection of Plasmodium falciparum. Parasitol. Int. 2001, 50, 249-257.

74. Wilson, D.W.; Crabb, B.S.; Beeson, J.G. Development of fluorescent Plasmodium falciparum for in vitro growth inhibition assays. Malar. J. 2010, 9, 152.

75. Che, P.; Cui, L.; Kutsch, O.; Cui, L.; Li, Q. Validating a firefly luciferase-based high-throughput screening assay for antimalarial drug discovery. Assay Drug Dev. Technol. 2012, 10, 61-68. 
76. Cui, L.; Miao, J.; Wang, J.; Li, Q.; Cui, L. Plasmodium falciparum: development of a transgenic line for screening antimalarials using firefly luciferase as the reporter. Exp. Parasitol. 2008, 120, 80-87.

77. Krettli, A.U.; Adebayo, J.O.; Krettli, L.G. Testing of natural products and synthetic molecules aiming at new antimalarials. Curr. Drug Targets 2009, 10, 261-270.

78. Gething, P.W.; Elyazar, I.R.; Moyes, C.L.; Smith, D.L.; Battle, K.E.; Guerra, C.A.; Patil, A.P.; Tatem, A.J.; Howes, R.E.; Myers, M.F.; et al. A long neglected world malaria map: Plasmodium vivax endemicity in 2010. PLoS neglect Trop. Dis. 2012, 6, e1814.

79. Guerra, C.A.; Howes, R.E.; Patil, A.P.; Gething, P.W.; Van Boeckel, T.P.; Temperley, W.H.; Kabaria, C.W.; Tatem, A.J.; Manh, B.H.; Elyazar, I.R.; et al. The international limits and population at risk of Plasmodium vivax transmission in 2009. PLoS Negl. Trop. Dis. 2010, 4, e774.

80. Boyd, M.F.; Stratman-Thomas, W.K.; Muench, H. The occurrence of gametocytes of Plasmodium vivax during the primary attack. Am. J. Trop. Med. Hyg. 1935, 16, 133-138.

81. Feachem, R.G.; Phillips, A.A.; Hwang, J.; Cotter, C.; Wielgosz, B.; Greenwood, B.M.; Sabot, O.; Rodriguez, M.H.; Abeyasinghe, R.R.; Ghebreyesus, T.A.; et al. Shrinking the malaria map: progress and prospects. Lancet 2010, 376, 1566-78.

82. Rodriguez, J.C.; Uribe, G.A.; Araujo, R.M.; Narvaez, P.C.; Valencia, S.H. Epidemiology and control of malaria in Colombia. Mem. Inst. Oswaldo Cruz 2011, 106, 114-122.

83. Gama, B.E.; Lacerda, M.V.; Daniel-Ribeiro, C.T.; Ferreira-da-Cruz Mde, F. Chemoresistance of Plasmodium falciparum and Plasmodium vivax parasites in Brazil: consequences on disease morbidity and control. Mem. Inst. Oswaldo Cruz 2011, 106, 159-166.

84. Oliveira-Ferreira, J.; Lacerda, M.V.; Brasil, P.; Ladislau, J.L.; Tauil, P.L.; Daniel-Ribeiro, C.T. Malaria in Brazil: An overview. Malar. J. 2010, 9, 115.

85. World Health Organization. World Malaria Report 2011; World Health Organization: Geneva, Switzerland, 2011; p.246.

86. Price, R.N.; Tjitra, E.; Guerra, C.A.; Yeung, S.; White, N.J.; Anstey, N.M. Vivax malaria: Neglected and not benign. Am. J. Trop. Med. Hyg. 2007, 77, 79-87.

87. Baird, J.K. Neglect of Plasmodium vivax malaria. Trends Parasitol. 2007, 23, 533-539.

88. Tjitra, E.; Anstey, N.M.; Sugiarto, P.; Warikar, N.; Kenangalem, E.; Karyana, M.; Lampah, D.A.; Price, R.N. Multidrug-resistant Plasmodium vivax associated with severe and fatal malaria: A prospective study in Papua, Indonesia. PLoS Med. 2008, 5, e128.

89. Genton, B.; D'Acremont, V.; Rare, L.; Baea, K.; Reeder, J.C.; Alpers, M.P.; Muller, I. Plasmodium vivax and mixed infections are associated with severe malaria in children: a prospective cohort study from Papua New Guinea. PLoS Med. 2008, 5, e127.

90. Beg, M.A.; Sani, N.; Mehraj, V.; Jafri, W.; Khan, M.A.; Malik, A.; Menezes, E.; Hussain, R.; Smego, R., Jr. Comparative features and outcomes of malaria at a tertiary care hospital in Karachi, Pakistan. Int. J. Infect. Dis. 2008, 12, 37-42.

91. Barcus, M.J.; Basri, H.; Picarima, H.; Manyakori, C.; Sekartuti; Elyazar, I.; Bangs, M.J.; Maguire, J.D.; Baird, J.K. Demographic risk factors for severe and fatal vivax and falciparum malaria among hospital admissions in northeastern Indonesian Papua. Am. J. Trop. Med. Hyg. 2007, 77, 984-991. 
92. Lampah, D.A.; Yeo, T.W.; Hardianto, S.O.; Tjitra, E.; Kenangalem, E.; Sugiarto, P.; Price, R.N.; Anstey, N.M. Coma associated with microscopy-diagnosed Plasmodium vivax: a prospective study in Papua, Indonesia. PLoS Negl. Trop. Dis. 2011, 5, e1032.

93. Kochar, D.K.; Das, A.; Kochar, S.K.; Saxena, V.; Sirohi, P.; Garg, S.; Kochar, A.; Khatri, M.P.; Gupta, V. Severe Plasmodium vivax malaria: a report on serial cases from Bikaner in northwestern India. Am. J. Trop. Med. Hyg. 2009, 80, 194-198.

94. Kochar, D.K.; Saxena, V.; Singh, N.; Kochar, S.K.; Kumar, S.V.; Das, A. Plasmodium vivax malaria. Emerg. Infect. Dis. 2005, 11, 132-134.

95. Tan, L.K.; Yacoub, S.; Scott, S.; Bhagani, S.; Jacobs, M. Acute lung injury and other serious complications of Plasmodium vivax malaria. Lancet Infect. Dis. 2008, 8, 449-454.

96. Bassat, Q.; Alonso, P.L. Defying malaria: Fathoming severe Plasmodium vivax disease. Nat. Med. 2011, 17, 48-49.

97. Anstey, N.M.; Russell, B.; Yeo, T.W.; Price, R.N. The pathophysiology of vivax malaria. Trends Parasitol. 2009, 25, 220-227.

98. Costa, F.T.; Lopes, S.C.; Albrecht, L.; Ataide, R.; Siqueira, A.M.; Souza, R.M.; Russell, B.; Renia, L.; Marinho, C.R.; Lacerda, M.V. On the pathogenesis of Plasmodium vivax malaria: perspectives from the Brazilian field. Int. J. Parasitol. 2012, 42, 1099-1105.

99. Lacerda, M.V.; Fragoso, S.C.; Alecrim, M.G.; Alexandre, M.A.; Magalhaes, B.M.; Siqueira, A.M.; Ferreira, L.C.; Araujo, J.R.; Mourao, M.P.; Ferrer, M.; et al. Postmortem characterization of patients with clinical diagnosis of Plasmodium vivax malaria: to what extent does this parasite kill? Clin. Infect. Dis. 2012, 55, e67-e74.

100. Alexandre, M.A.; Ferreira, C.O.; Siqueira, A.M.; Magalhaes, B.L.; Mourao, M.P.; Lacerda, M.V.; Alecrim, M. Severe Plasmodium vivax malaria, Brazilian Amazon. Emerg. Infect. Dis. 2010, 16, 1611-1614.

101. de Lacerda, M.V.; Zackiewicz, C.; Alecrim, W.D.; Alecrim, M. The neglected Plasmodium vivax: are researchers from endemic areas really concerned about new treatment options? Rev. Soc. Bras. Med. Trop. 2007, 40, 489-490.

102. Price, R.N.; Douglas, N.M.; Anstey, N.M.; von Seidlein, L. Plasmodium vivax treatments: What are we looking for? Curr. Opin.Infect. Dis. 2011, 24, 578-585.

103. Carlton, J.M.; Sina, B.J.; Adams, J.H. Why Is Plasmodium vivax a neglected tropical disease? PLoS Negl.Trop. Dis. 2011, 5, e1160.

104. Rieckmann, K.H.; Davis, D.R.; Hutton, D.C. Plasmodium vivax resistance to chloroquine? Lancet 1989, 2, 1183-1184.

105. Harinasuta, T.; Suntharasamai, P.; Viravan, C. Chloroquine-resistant falciparum malaria in Thailand. Lancet 1965, 2, 657-660.

106. Sumawinata, I.W.; Bernadeta; Leksana, B.; Sutamihardja, A.; Purnomo; Subianto, B.; Sekartuti; Fryauff, D.J.; Baird, J.K. Very high risk of therapeutic failure with chloroquine for uncomplicated Plasmodium falciparum and P. vivax malaria in Indonesian Papua. Am. J. Trop. Med. Hyg. 2003, 68, 416-420.

107. Baird, J.K.; Wiady, I.; Fryauff, D.J.; Sutanihardja, M.A.; Leksana, B.; Widjaya, H.; Kysdarmanto; Subianto, B. In vivo resistance to chloroquine by Plasmodium vivax and Plasmodium falciparum at Nabire, Irian Jaya, Indonesia. Am. J. Trop. Med. Hyg. 1997, 56, 627-631. 
108. Sutanto, I.; Suprijanto, S.; Nurhayati; Manoempil, P.; Baird, J.K. Resistance to chloroquine by Plasmodium vivax at Alor in the Lesser Sundas Archipelago in eastern Indonesia. Am. J. Trop. Med. Hyg. 2009, 81, 338-342.

109. Ratcliff, A.; Siswantoro, H.; Kenangalem, E.; Wuwung, M.; Brockman, A.; Edstein, M.D.; Laihad, F.; Ebsworth, E.P.; Anstey, N.M.; Tjitra, E.; et al. Therapeutic response of multidrugresistant Plasmodium falciparum and $P$. vivax to chloroquine and sulfadoxine-pyrimethamine in southern Papua, Indonesia. Trans. R.oyal Soc. Trop. Med. Hyg. 2007, 101, 351-359.

110. Young, M.D.; Burgess, R.W. Pyrimethamine resistance in Plasmodium vivax malaria. Bull. World Health Org. 1959, 20, 27-36.

111. Baird, J.K. Resistance to therapies for infection by Plasmodium vivax. Clin. Microbiol. Rev. 2009, 22, 508-534.

112. Russell, B.; Chalfein, F.; Prasetyorini, B.; Kenangalem, E.; Piera, K.; Suwanarusk, R.; Brockman, A.; Prayoga, P.; Sugiarto, P.; Cheng, Q.; et al. Determinants of in vitro drug susceptibility testing of Plasmodium vivax. Antimicrob. Agents Chemother. 2008, 52, 1040-1045.

113. Sharrock, W.W.; Suwanarusk, R.; Lek-Uthai, U.; Edstein, M.D.; Kosaisavee, V.; Travers, T.; Jaidee, A.; Sriprawat, K.; Price, R.N.; Nosten, F.; et al. Plasmodium vivax trophozoites insensitive to chloroquine. Malar. J. 2008, 7, 94.

114. Price, R.N.; Auburn, S.; Marfurt, J.; Cheng, Q. Phenotypic and genotypic characterisation of drug-resistant Plasmodium vivax. Trends Parasitol. 2012, 28, 522-529.

115. Chotivanich, K.; Udomsangpetch, R.; Chierakul, W.; Newton, P.N.; Ruangveerayuth, R.; Pukrittayakamee, S.; Looareesuwan, S.; White, N.J. In vitro efficacy of antimalarial drugs against Plasmodium vivax on the western border of Thailand. Am. J. Trop. Med. Hyg. 2004, 70, 395-397.

116. Kerlin, D.H.; Boyce, K.; Marfurt, J.; Simpson, J.A.; Kenangalem, E.; Cheng, Q.; Price, R.N.; Gatton, M.L. An analytical method for assessing stage-specific drug activity in Plasmodium vivax malaria: implications for ex vivo drug susceptibility testing. PLoS Negl. Trop. Dis. 2012, 6, e1772.

117. Marfurt, J.; Chalfein, F.; Prayoga, P.; Wabiser, F.; Kenangalem, E.; Piera, K.A.; Fairlie, D.P.; Tjitra, E.; Anstey, N.M.; Andrews, K.T.; et al. Ex vivo activity of histone deacetylase inhibitors against multidrug-resistant clinical isolates of Plasmodium falciparum and P. vivax. Antimicrob. Agents Chemother. 2011, 55, 961-966.

118. Tasanor, O.; Noedl, H.; Na-Bangchang, K.; Congpuong, K.; Sirichaisinthop, J.; Wernsdorfer, W.H. An in vitro system for assessing the sensitivity of Plasmodium vivax to chloroquine. Acta Trop. 2002, 83, 49-61.

119. Mazier, D.; Renia, L.; Snounou, G. A pre-emptive strike against malaria's stealthy hepatic forms. Nat. Rev. Drug Discov. 2009, 8, 854-864.

120. Hollingdale, M.R.; Collins, W.E.; Campbell, C.C. In vitro culture of exoerythrocytic parasites of the North Korean strain of Plasmodium vivax in hepatoma cells. Am. J. Trop. Med. Hyg. 1986, 35, 275-276.

121. Hollingdale, M.R.; Collins, W.E.; Campbell, C.C.; Schwartz, A.L. In vitro culture of two populations (dividing and nondividing) of exoerythrocytic parasites of Plasmodium vivax. Am. J. Trop. Med. Hyg. 1985, 34, 216-222. 
122. Mazier, D.; Collins, W.E.; Mellouk, S.; Procell, P.M.; Berbiguier, N.; Campbell, G.H.; Miltgen, F.; Bertolotti, R.; Langlois, P.; Gentilini, M. Plasmodium ovale: In vitro development of hepatic stages. Exp. Parasitol. 1987, 64, 393-400.

123. Mazier, D.; Landau, I.; Druilhe, P.; Miltgen, F.; Guguen-Guillouzo, C.; Baccam, D.; Baxter, J.; Chigot, J.P.; Gentilini, M. Cultivation of the liver forms of Plasmodium vivax in human hepatocytes. Nature 1984, 307, 367-369.

124. Hastings, M.D.; Porter, K.M.; Maguire, J.D.; Susanti, I.; Kania, W.; Bangs, M.J.; Sibley, C.H.; Baird, J.K. Dihydrofolate reductase mutations in Plasmodium vivax from Indonesia and therapeutic response to sulfadoxine plus pyrimethamine. J. Infect. Dis. 2004, 189, 744-750.

125. Krudsood, S.; Tangpukdee, N.; Wilairatana, P.; Phophak, N.; Baird, J.K.; Brittenham, G.M.; Looareesuwan, S. High-dose primaquine regimens against relapse of Plasmodium vivax malaria. Am. J. Trop. Med. Hyg. 2008, 78, 736-740.

126. Ku, M.J.; Dossin, F.M.; Choi, Y.; Moraes, C.B.; Ryu, J.; Song, R.; Freitas-Junior, L.H. Quantum dots: A new tool for anti-malarial drug assays. Malar. J. 2011, 10, 118.

127. Karl, S.; Wong, R.P.; St Pierre, T.G.; Davis, T.M. A comparative study of a flow-cytometrybased assessment of in vitro Plasmodium falciparum drug sensitivity. Malar. J. 2009, 8, 294.

128. Malleret, B.; Claser, C.; Ong, A.S.; Suwanarusk, R.; Sriprawat, K.; Howland, S.W.; Russell, B.; Nosten, F.; Renia, L. A rapid and robust tri-color flow cytometry assay for monitoring malaria parasite development. Sci. Rep. 2011, 1, 118.

129. Meister, S.; Plouffe, D.M.; Kuhen, K.L.; Bonamy, G.M.; Wu, T.; Barnes, S.W.; Bopp, S.E.; Borboa, R.; Bright, A.T.; Che, J.; et al. Imaging of Plasmodium liver stages to drive next-generation antimalarial drug discovery. Science 2011, 334, 1372-1377.

(C) 2013 by the authors; licensee MDPI, Basel, Switzerland. This article is an open access article distributed under the terms and conditions of the Creative Commons Attribution license (http://creativecommons.org/licenses/by/3.0/). 